The European Legacy

Toward New Paradigms

ISSN: 1084-8770 (Print) 1470-1316 (Online) Journal homepage: http://www.tandfonline.com/loi/cele20

\title{
A Decadence Baedeker: D'Annunzio's The Triumph of Death
}

\section{Joseph Galbo}

To cite this article: Joseph Galbo (2016): A Decadence Baedeker: D'Annunzio's The Triumph of Death, The European Legacy, DOI: 10.1080/10848770.2016.1239452

To link to this article: http://dx.doi.org/10.1080/10848770.2016.1239452

曲 Published online: 21 Oct 2016.

Submit your article to this journal

Q View related articles $₫$

View Crossmark data $₫$ 


\title{
A Decadence Baedeker: D'Annunzio's The Triumph of Death
}

\author{
Joseph Galbo \\ Department of Social Science, University of New Brunswick, 100 Tucker Park Road, Saint John, New Brunswick \\ E2L 4L5, Canada
}

\begin{abstract}
This article investigates how Gabriele D'Annunzio's The Triumph of Death brings together Nietzsche's ideas and Wagner's music and interweaves them with the motifs of literary Decadence and the author's own particular sexual politics. The novel is an experimental text striving to be a Gesemtkunstswerk, an integrated work that incorporates music, painting, poetry, regional folklore, and private thoughts about personal and national power. I discuss the novel's themes of violent sexuality and the anxiety of powerlessness and explore their implications for the fascist political aesthetics in which D’Annunzio played a pioneering role.
\end{abstract}

\section{KEYWORDS}

D’Annunzio; fascism; political aesthetics; cultural politics; Wagner; Nietzsche

\section{Introduction}

It was not uncommon at the turn of the twentieth century, wrote Philippe Jullian, one of D’Annunzio's more lively biographers, for a young aesthete from Paris or London travelling to Rome to pack along with their Baedeker a copy of Gabriele D'Annunzio's Il Piacere [The Child of Pleasure] (1889) when visiting the piazzas and parks described in that novel. ${ }^{1}$ Il Piacere offered non-Italian readers a tourist guide to the monuments of Rome. Il Trionfo della Morte [The Triumph of Death] (1894), on the other hand, introduces both the Italian and non-Italian reader to the province of Abruzzo, a "wild" land inhabited by "barbarians" seemingly untouched by the modern world, as the setting for the psychological unraveling of the main protagonist Giorgio Auspiria. ${ }^{2}$ The Triumph of Death is an overwhelmingly male text, concerned with the loss of masculine will that leads its Giorgio to murder his lover Ippolita Sanzio and then to commit suicide.

D’Annunzio's earlier novella, Giovanni Episcopo (1892), was strongly influenced by the work of Dostoevsky and the Russian psychological novels, and in his preface he emphasized the need for a new style of writing. ${ }^{3}$ That book, however, was a personal and public disappointment. The Triumph of Death was thus conceived as a Gesemtkunstswerk, a work that incorporates music, paintings, poetry, and folklore, while expressing the personal values of its author. D’Annunzio associated his ambitious goal with Richard Wagner, and more significantly with Bayreuth, the theatre where Wagner had complete dominion over the performance of his works. 
D'Annunzio struggled with the writing of The Triumph of Death more than with any other of his novels and Giorgio Auspiria emerges as one of his most complex literary figures. D'Annunzio, however, was not satisfied with the result and called the novel a "rotten corpse." Nevertheless, it is arguably both an important artistic achievement and a telling document of its time, a guidebook to the relatively unknown province of the Abruzzo as well as to the ideas of Nietzsche and the operas of Wagner, which D'Annunzio interweaves with the motifs of literary Decadence as well as his own sexual politics.

In this essay I examine the themes and sources of the novel as part of the "structure of feelings and references" that circulated within the broader European culture of the time. D'Annunzio's work is both a product of his setting and a source for understanding it. The novel portrays the Abruzzo region as a mystical land populated by both potential supermen and lesser beings, and as the site where the main protagonist must confront his own weakness. Giorgio's murderous desires are related to his loss of control over Ippolita, cast as the dangerous "other," whose murder, along with Giorgio's suicide, are rendered as an aesthetic triumph. There is much in the novel to admire as well as to deplore: it is an operatic text full of display and unbuttoned emotions. Since D'Annunzio's attitude to fascism is well known, in my conclusion, I examine the links between the novel's themes of sexuality and power to what Walter Benjamin called the fascist "aestheticization of politics," the broadening of politics to include theatre, music and ritual, so as to maximize its popular appeal. ${ }^{5}$

\section{Violence, Barbarians, and the National Imaginary}

D'Annunzio began his literary career as a regional writer in the southern province of the Abruzzo, and this locale became an essential element of his personal identity and his politics. His early short stories were sharp explorations of local life written in the homegrown style of naturalism or verismo. The influential work of several Italian writers-Giovanni Verga, Luigi Capuana, Salvatore Di Giacomo, Grazia Deledda and Matilde Serao, among others-had by the end of the nineteenth century made verismo the dominant literary form. His early writing consciously copied Verga's style, but without Verga's empathy in representing scenes of violence. D'Annunzio was a forensic rather than a sympathetic observer. ${ }^{6}$ The marketplace rewarded the sexual cruelty of these works, which were usually set in exotic locales where the remote natural scenery played a significant distancing role. He no doubt exploited the prurient interests of the literary market, highly aware of what sold, because he was usually in need of money. ${ }^{7}$ Perhaps not surprisingly, the more gory his stories, the better they sold, contributing to his reputation as the enfant terrible of Italian literature.

Mario Praz in his magisterial The Romantic Agony discusses the central themes of D'Annunzio's works: his misogyny, his attraction to suicides and murders, and his descriptions of cruelty and bloody horrors, reminiscent of the scenes performed in the Grand Guignol Parisian theatre where people were blinded and hacked to death with abandon. Praz considers these elements as "natural" to D'Annunzio's southern background: that part of Italy in which "more than any other the general level of life is instinctive and primitive, a real 'Italia barbara' the 'remota e inculta' province of the Abruzzo." Only such a place could produce what Praz calls a "spirito crudo" (raw nature) like D’Annunzio, an outsider who forced his way into the metropolitan centers and assimilated its values only imperfectly. "D’Annunzio," he writes, "is primarily an Abruzzese who had made his second home in Tuscany, secondarily an Italian who had made his second home in Paris. But neither Tuscan 
nor French culture was native to him, nor an essential part of him." Once he had crossed the exclusionary national and class barriers, he displayed the qualities of an ostentatious parvenu much like a "barbarian" who, having scaled the walls and "exalted all at once to the throne of Byzantium, covers himself with all the jewels he can lay hands on."

Contemporary critics may put the phrase "spirito crudo" in quotation marks to distance themselves from Praz's stereotypical portrayal, but there is still widespread acceptance of his authoritative claim that the shocking violence in D'Annunzio's work can be largely explained by his southern background, particularly because at the time these provinces were barely integrated into the national life of the newly united Italy. Even an otherwise astute twentieth-century critic like Anthony Rhodes cannot steer away from such evaluations: "In... Il Trionfo della Morte, D’Annunzio catches something most true to Abruzzese life-the paganism bred in the blood of its people, mixed with the ferocity of Christian bigotry." Rhodes is merely stating something considered axiomatic, part of the official learning and institutional knowledge that positions the Italian south as subject matter and terrain for literary and biographical explanation. D'Annunzio contributed to the durability of this discursive portrayal, giving it a Wagnerian and Nietzschean inflection, and made it a central aspect of his politics. His Abruzzo is portrayed as simultaneously a lesser and a larger world, populated by brutalized people steeped in ignorance, grinding poverty and religious superstition, who are also larger than life heroes endowed with a natural Dionysian sensuality and thus potentially vital to the nation. ${ }^{10}$

When in 1871 Rome became the capital of the newly united Italy the Abruzzo became the object of a great number of ethnographic studies, including those of Antonio De Nino, Giovanni Pansa, and Gennaro Finamore, which contributed to its representation as a mythic and primitive land. ${ }^{11}$ The ethnographical search for the remnants of an archaic folk culture was strongly associated with Italy's state building and its political narratives of linking the past with the present. With the rise of European nationalism, writers were intent on demonstrating that a rich "authentic" local heritage was essential to the cultural definition of the modern nation. James Macpherson, under the pseudonym of Ossian, "discovered" ancient Gaelic poems; Sir Walter Scott collected and edited songs and tales of the Scottish Highlands; and Jacob and Wilhelm Grimm gathered German fairy tales: these are just three well-known examples of the use of folklore to inspire national identity. The linguistic studies of Johann Gottfried Herder emphasized the importance of poetry and language in the creation of a nation while the works of others influenced by the Romantics contributed to political concepts about "folk culture" as something to be studied, or if necessary invented, in order to promote a cohesive national culture. ${ }^{12}$

D'Annunzio was well aware of the Italian ethnographic works on the Abruzzo. He read the account of Italian diplomat and journalist Primo Levi, Abruzzo Forte e Gentile: Impressione d'occhio e di coure (1882), which mixed local folklore with the Risorgimento message that the strength of the people would define the new nation. While working on The Triumph of Death, he consulted De Nino's works Proverbs of the Abruzzo (1877) and The Messiah of the Abruzzo (1890), as well as the two volumes by English traveler and early anthropologist Keppel Richard Craven, Excursion in the Abruzzi and Northern Provinces of Naples (1838). These studies provided a detailed description of the life and habits of the people of the Abruzzo and were part of what in another context Raymond Williams calls "the structures of references and feelings" that are continually invoked, reiterated, and used for understanding and interpreting aspects of the ethnic nation. ${ }^{13}$ 
D'Annunzio's Abruzzo was a magical land of nature and primitives very much in line with nationalistic narratives, but in The Triumph of Death he filled the region with the unfit, the subhuman and the monstrous, alongside the potential Superman. These contrasting representations do not arise simply from some pre-existing coherent idea that a writer autonomously creates, but are part of a set of conventions, attitudes, and theories that appear at a particular historical juncture and work to shape a national imaginary. Since these structures of references are inscribed in the discursive practices of a given period, they can be identified as central tropes in its narratives and can have a formative effect on the political and national perceptions of readers.

D'Annunzio's appropriation of Nietzsche's and Wagner's work illustrates how such a structure of references and feelings operates in a political and literary context. When he ran for Parliament for the district of Ortona in the province of the Abruzzo in 1897, three years after The Triumph of Death was published, the region was populated by poor peasants and fisher folk ruled by a tiny educated elite, which is why he saw the election as an opportunity for personal glorification: "I have come back from an electoral trip," he wrote to a friend, "and my nostrils are still full of an acrid smell of humanity." ${ }^{4} \mathrm{He}$ had no intention of representing the democratic wishes of his small constituency but rather, recognized that his own political power was tied to how he could transform their minds and lead them into action. He expressed this view in his election speeches, which were mostly reiterations of the Nietzschean elitist ideas which he set forth in his 1892 essay, "The Beast Who Wills" (La bestia elettiva). ${ }^{15}$

The only translation of his work to appear during Nietzsche's working life and gain international attention was "Richard Wagner in Bayreuth" (1876), which was published in 1877 in France. In 1888, a year before his mental breakdown in Turin, Nietzsche wrote a solicitous letter to the leading Italian poet Giosuè Carducci with whom he felt a shared intellectual interest, urging him to promote the anticlerical and anti-Wagnerian work he had just finished and to translate his essays "The Case of Wagner" and "Nietzsche contra Wagner" into Italian. ${ }^{16}$ In these essays Nietzsche attacked Wagner for contributing through the mysticism and fatalism of his musical dramas to the degeneration of European culture, and criticized him for descending from the heroic and aristocratic Siegfried to the more populist and life-renouncing Parsifal. The letter, however, was never finished or sent, and Nietzsche remained relatively unknown to a wider Italian audience until the publication of D’Annunzio's novel. ${ }^{17}$

D'Annunzio's panegyric to nature and barbarian vitality draws on various sources, including Carducci's Barbarian Odes, poems that evoke and praise the pre-Christian ancient world. ${ }^{18}$ D'Annunzio strove to capture the imagery and emotions of a pagan world where nature and Eros were synthesized to pose a challenge to the ascetic morality of Christianity. His desire to gain self-mastery, in keeping with the laws of nature and free from a weak slave morality, combined, however, with a monumental arrogance. From Nietzsche, he extracted a definition of barbarian power that served his own political purpose and which some critics have ironically called "Nietzsche Italian Style." 19 He began to read Nietzsche in an anthologized French translation in 1892 and soon realized that the idea of the Üebermensch in Thus Spoke Zarathustra was at least on the surface similar to his own idea of the Superman.

The Superman, for D'Annunzio, was an aesthetic concept rather than a philosophical critique of morality and power. He focused almost exclusively on inequality as a natural occurrence and on the forceful imposition of personal will, but ignored Nietzsche's critical 
transvaluation of all values. While Ressentiment, the psychological mechanisms through which people blame their own frustrations on "the other," was at the root of Nietzsche's penetrating understanding of the master-slave relationship, D’Annunzio was chiefly interested in masters and their exceptional self-regard. He thus advanced a narrower interpretation of Nietzsche as the philosopher of will, first publicized shortly after Nietzsche's illness and public silence, the most egregious example of which was his sister's posthumous publication of the The Will to Power in $1900 .^{20}$

Though neither Nietzsche nor Wagner was particularly well known in Italy at the time, D’Annunzio always kept a sharp eye for emerging cultural trends. Wagner's opera Lohengrin was first performed in Bologna in 1871, and Tristan und Isolde was staged there in 1888. In the land of Verdi, Wagner was naturally viewed with suspicion, though he had his own devotees. And while the first of Nietzsche's works to be translated into Italian-Beyond Good and Evil (1886) - was published in Turin in 1898, his ideas had been drawing attention in salons and intellectual circles across Italy. Similarly, the first positive review of The Birth of Tragedy (1886) was published in the same year in the newly founded Rivista Europea, which pleased Nietzsche immensely. ${ }^{21}$ D'Annunzio had moved to Naples while working on The Triumph of Death, and it was there that he deepened his understanding of both Wagner and Nietzsche and joined the public debates about the two in his journalistic writings.

In "The Case of Wagner" Nietzsche argued that Wagner was a symptom of a deeper sickness infesting Europe: nihilism. If one took away the theatricality from Wagner's operas, he asserted, his superficially seductive music would be the worst that had ever been written. Wagner's art was diseased: “The problems he sets on the stage are all concerned with hysteria; the convulsiveness of his emotions, his over-excited sensitiveness." 22 Wagner, in short, was a Decadent whose overwrought sensibility made both his music sick and all of European culture sick. The great struggle for a philosopher in an age of decadence, Nietzsche argued, was to think clearly so as to overcome this form of emotional turbulence: "I am as much a child of my age as Wagner-i.e, I am a decadent. The only difference is that I recognized the fact, that I struggled against it. The philosopher in me struggled against it." ${ }^{23}$

While D'Annunzio found Nietzsche's Superman useful as a metaphor for transcending decadence, he felt that Wagner brought him closer to modernity than any other philosopher. He agreed with Nietzsche that they were living in an age of nihilism and insisted that one needed to look deep into the roots of morbid obsessions in order to understand and guard against them and, in Nietzsche's words, to overcome them. Yet Nietzsche himself was perhaps "hysterical" in his critique of Wagner. D'Annunzio thought that Nietzsche's charge against Wagner's music as catering to public taste was misplaced, for the mental habits of every historical period inevitably influenced the works of art produced in it. Thus artists who wanted to grasp the national mood had to be attentive to popular sentiments. More importantly, he felt that Wagner understood that people had a spiritual thirst. His music was great because it expressed the inner worlds of his characters and tapped into "the most occult part of our private life," ${ }^{4}$ regardless of the theatrical scaffold. This is what appealed to him in Wagner's music and, indeed, many years later, he and his new lover, Elenora Duse, were involved in an ambitious but unsuccessful project to build a monumental national theatre in the Roman Alban Hills that would rival Wagner's Bayreuth.

D'Annunzio's idiosyncratic fusion of Wagner and Nietzsche was consequential for the way he perceived both the Abruzzo and politics more generally. He longed to create, through his own literature, a Latin barbarian, a leader ready to raise a new banner and invigorate an 
elite gone soft in a democratic world. Alberto Asor Rosa describes his representation of the Abruzzese peasantry and fisher folk as "barbaric populism," a racially inflected discourse about the Italian people that was both populist and elitist. ${ }^{25}$ D'Annunzio's peasantry, Asor Rosa writes, is steeped in nature, often violent, religiously fanatical, and searching for the guidance of a strong leader, while his ideal hero is naturally priapic, aristocratic in spirit, and mystical. Wishing to create an artistic and national masterpiece, D'Annunzio increasingly associated politics with a theatre that could shape the inner feelings of the nation. Political leadership was directly linked for him with the figure of a Superman who could inspire the turbulent crowd with his eloquence and violent nature.

\section{From Verismo to Gesemtkunstswerk}

The drive to explore local dialects and the rituals of everyday life in remote areas of the newly united Italy gave rise to a large body of creative work that was associated with the term "verismo," or realism. An emblematic example of this style was Giovanni Verga's "Cavelleria rusticana," a story in which the romantic entanglements of ordinary Sicilians were resolved violently. Verga's story inspired the first verismo opera by Pietro Mascagni, which premiered in May 1890. The literature and opera of verismo were inseparable from the desire to create a hegemonic, popular national identity. ${ }^{26}$ The return to the city or countryside and to regional habits and customs was thus an imaginative way of finding and defining the nation.

D'Annunzio's early work falls within this discursive context, though by the time he wrote the Triumph of Death (1894) he was already exploring new forms of representation having benefited from his connections with a group of artists loosely associated with the painter Francesco Paolo Michetti (1851-1929). A successful artist from the Abruzzo and eighteen years older than D'Annunzio, Michetti played the role of spiritual father to the younger Gabriele, who was accepted into the group when he was still a student at Cicognini College in Tuscany. The Triumph of Death was mainly written while he stayed in Michetti's villa Francavilla a mare, a former convent turned guest-house, which later became a magnet for a group of Italian intellectuals known as Il Cenacolo (the Symposium) who gathered there each summer to talk about art. Paola Sorge has recently examined the exchange of influences among this remarkable group, which she describes as "a rare phenomenon if not unique, in the history of modern Italian art." ${ }^{27}$ The more notable members of this group included Francesco Paolo Tosti, a composer who later set many of D’Annunzio's verses to music and an ethnomusicologist who collected Abruzzese peasant songs, the sculptor Constantine Barbarella, and the ethnographer Guido Boggiani, whose later studies and photographs of the tribes of Brazil and Paraguay were to influence Claude Lévi-Strauss. All of them were animated by the dream, inspired in part by Wagner, of creating great art that drew on all the other arts.

In 1882 D'Annunzio accompanied Michetti to witness the religious pilgrimage that became the basis of one of his most famous paintings, Il Voto (The Vow, 1883), which depicts villagers with bloodied tongues licking the floor of a church as they crawl towards a miraculous silver statue of San Pantaleone. Michetti's paintings and photographs of religious festivals in the Abruzzo were remarkably popular. Even today we refer to his photographs of the snake festival of Coculla and the pilgrimage of Casalbordino, and to his Mattinata, which portrays five singing peasant girls surrounded by a local crowd, and I Morticelli, a striking painting of a funeral cortège of dead children, as part of the ethnographic record of life at 
the turn of the century. ${ }^{28}$ These specific visual representations, which figure prominently in The Triumph of Death, were part of D'Annunzio's aesthetic plan to write a Gesemtkunstswerk.

Although D’Annunzio had already been labeled a "decadent" and a "symbolist" in 1889 with the publication of Il Piacere, there were innumerable points of convergence as well as divergence between Decadence and verismo. Veristi writers, like other naturalist writers, set out to construct a model of the real through an allegedly transparent language but soon realized that their powers of observation and their use of a fixed point of view, no matter how controlled and scientific, were insufficient. Having gone as far as he could in examining the objects of his sensations, D’Annunzio now began to study sensations themselves. Wagnerian opera provided him with a model of a modern mythic framing narrative.

There was general agreement among leading Europeans who were attuned to Wagner's music and read the influential La Révue Wagnérienne that the complex structure of the operas unlocked the door into myth. Indeed, Claude Lévi-Strauss affirmed that Wagner was "the father of the structural analysis of myth." ${ }^{29}$ Wagner's operas, like myths, created a sensation of simultaneity where time and space were confused and dream and reality interpenetrated. While living in Naples D'Annunzio had become obsessed with Wagner's music and hounded his composer friend Niccolò van Westerhout to play Wagner's operas on the piano while he closely followed the librettos. ${ }^{30}$ He learned from Wagner how the great surges of emotion released by the music were controlled through patterns, repetitions, and variations.

A direct illustration of how he assimilated Wagner's musical structures into The Triumph of Death is found in the novel's last part, which describes Giorgio's experience of listening to the Mystic Gulf movement from Tristan und Isolde. As in the works of the early modernists, this scene presents a direct challenge to the reader to invent a new way of listening and reading, through its use of the stream of consciousness, lietmotif, and repetition. By using these literary strategies the stable subject that alone apprehends reality dissolves into a whirling flux of sensations that are conveyed in a language that has the richness and subtlety of poetry. Some critics have complained that D'Annunzio remains stuck in his own fascination with the musical aspect of language. His prose is loaded with euphonious words that often signify nothing except his own virtuosity, which may have incited Henry James to accuse him of producing a suffocating and gaseous "bad air." ${ }^{31}$ D'Annunzio's lyricism often tests the sensibility of even the most accommodating reader, while his characters are never fully developed but function as mythic types and foregone conclusions. Nonetheless, in his works D'Annunzio masterfully presented what James called an "exasperated sensibility," usually of a man ready to commit violence, ${ }^{32}$ through whom he elaborated political and psychological ideas that would have had far less permanence had they not been part of his art.

\section{Breaking Down the Barriers: Life, Art, and Politics}

D'Annunzio was writing at a time when the concept of the nation, shaped in the crucible of the Risorgimento, was being seriously contested by a new disillusioned and searching generation. ${ }^{33}$ Modernization had intensified class tensions and increased the rift between North and South; the politics of transformismo had institutionalized corruption, while the first attempts at imperial expansions into Africa turned out to be humiliating national defeats. Meanwhile, new narratives emerged and influenced cultural and political interpretations of the nation. These ranged from Lombrosian and Social Darwinist discourses with 
their emphasis on survival of the fittest and fear of degeneration, to the elitism of Nietzsche, Gaetano Mosca, and Vilfredo Pareto, to more collective ethno-nationalist narratives such as that advanced by Maurice Barrés, whose work most resembles D'Annunzio's, which emphasized a folkloric blood and soil ideology and the idea that the most authentic national identity was to be found in the traditions and religions of untouched regions. ${ }^{34}$ D'Annunzio responded to these discourses by expressing his own national aspirations, at first obliquely and later on more directly.

Alongside his political ideals, D’Annunzio invented himself as a larger than life Byronic figure. The D'Annunzian self had all the qualities of the Romantic Decadent: he aspires to change life into art, to substitute ethics with aesthetics, and in affirming himself to overturn and crush others. In The Triumph of Death the line separating fiction and biography is paperthin and the author's values and sexual adventures are put on public display for the purpose of self-promotion. Ippolita Sanzio, for example, was closely modelled on D'Annunzio's lover Barbara Leone. Her real name was Elvira Natalia Fratenelli but D'Annunzio changed it, saying the new name suited her better, and also called her by the pet name Ippolita. Fratenelli had been pressured by her lower-middle-class family to marry nobility, but her husband, Count Ercole Leone, turned out to be a repellent character with a questionable title and little money. The marriage lasted a few weeks; the count vanished but periodically returned to exercise his conjugal rights. Fratenelli was unhappy for obvious reasons, including a sexually transmitted disease that her husband probably passed on to her and an abortion that left her unable to bear children. An avid letter writer, Fratenelli wrote D’Annunzio over 1000 love-letters during their five-year relationship, some of which he incorporated almost verbatim into The Triumph of Death.

In his final, autobiographical book, Libro Segreto (1935), D'Annunzio noted that Fratenelli's infertility and paleness were the sources of his own erotic obsession with her. Ippolita is marked by similar characteristics in the earlier stages of the novel. By 1893, however, D'Annunzio's relationship with Fratenelli was over and the influence of his new lover, the Sicilian princess Maria Gravina Cruyllas, became more pronounced in the novel. Cruyllas adds a dangerous dimension to Ippolita as the novel moves from the abandoned passion Giorgio feels for her to his more desperate suicidal feelings in the face of a woman who is becoming stronger, physically more resilient and emotionally more independent. These changes are marked by a shift from her earlier paleness: she develops a darker complexion, "like an olive" (Il Trionfo, 211).

D'Annunzio's relationship to his father is also examined in the novel with psychological insights worthy of Dostoevsky, whom, as noted earlier, he admired. Some biographers have suggested that his father's death from a heart attack in 1893 was hastened by his reading his son's hateful portrayal of him. D'Annunzio Sr. drove the family into debt in order to maintain a series of mistresses. He squandered the inheritance his great-uncle left his son Gabriele. The family villa was sold and the house mortgaged. Much of the description of the paternal home in The Triumph of Death is painfully close to real life. D'Annunzio also used the novel to examine his own sexual cravings and his fear that he was doomed by "heredity" and "blood" to repeat the sins of his father. His justly famous account of Giorgio's father is a pitiless look into the cycle of oppression within families and the power of the flesh: "I am that man's son!" (86), says the dejected Giorgio on seeing in his father his own horrid reflection as a decaying voluptuary. 
Similarly, D'Annunzio dedicated The Triumph of Death to his friend Michetti, whom he addresses as the "Cenobiarca" (ruler of the convent) in the preface: "We bend our ears to the voice of the magnanimous Zarathustra, O Ruler of the Convent; and we prepare in our art with an assured faith, the advent of the ÜEBERMENSCH, the Superman." ${ }^{5}$ The Triumph of Death is the first of a series of works in which D'Annunzio intended to introduce a new political aesthetic that would be more fully developed in future novels The Virgins of the Rocks (1897), The Flame (1900), Forse che si, Forse che no (1910), and the play La Nave (1908). These works were published during the heyday of European imperialism and aggressive nationalism when the relationship between politics and art was becoming increasingly problematic. By making the promotion of imperialism a key focus in their works, D’Annunzio along with Rudyard Kipling and others tied their literary creations to a larger political project. In The Triumph of Death the theme of a national empire is a shadowy presence operating much like what Frederic Jameson calls a text's "political unconscious."36 The role of women and their psychological conquest and subjugation is, however, plainly evident. The novel is a vehicle for D'Annunzio's ideas about sexuality and male will, and while it is not about national imperialism directly, it is about power.

\section{The Decadent Anti-Hero and the Ecstasy of Death}

While Giorgio's character in The Triumph of Death is highly autobiographical and perhaps comes close to being D'Annunzio's alter ego, he is simultaneously a literary creation. As such, he appears to come straight from the pages of J. K. Huysmans' Against Nature, whose neurasthenic protagonist, Des Esseintes, hates the modern world, lives sheltered in his bizarre imagination, and feeds on the ideas of the Marquis de Sade, Arthur Schopenhauer, Algernon Swinburne, and the music of Wagner. ${ }^{37}$ While Ippolita is part Elvira Natalia Fratenelli and part Maria Gravina, she too belongs to the established literary tradition of the femmes fatales and belles dames sans merci. In addition to the specific biographical and generic literary influences, however, the conflict between Giorgio and Ippolita is intertwined with the landscape and people of the Abruzzo in ways that move the narrative beyond the personal into the mythical and the national imaginary.

The Triumph of Death is a striking example of Italian decadentismo where the shadow of death falls heavily over eroticism. For two years Giorgio has been having an affair with Ippolita, who comes from the Trastervere, a lower-middle-class area of Rome. A fiercely passionate woman, Ippolita is someone Giorgio can control and turn into an object of his sexual fantasies. "I am his creation" (41), she says, on one of the few occasions she speaks in her own voice. When the lovers are introduced in the first pages of the book, they witness the aftermath of the suicide of a young woman who has jumped from the cliff of the Pincio Gardens in Rome. From the moment they see the bloodstains on the pavement, death and dying follow the lovers as a leitmotif.

What first draws Giorgio to Ippolita is her sickness: her "supernatural pallor" (33), her epilepsy, and her barrenness: "her entrails have been visited by a curse" (307). Her having the same name as his dead sister stirs in him incestuous feelings for a "sister-lover" and his perverse delight in his transgressive sexual desires. Giorgio appears to be a man who finds pleasure only in his morbid imagination. When the two lovers are preparing to celebrate their second anniversary and consider where to spend their romantic tryst, Ippolita refers to the city of Orvieto in a Baedeker: "What a number of monasteries! How many convents! 
It must be a strange place. Shall we go to Orvieto?" (24). Giorgio imagines the silent city of Orvieto where they can spend a month of uninterrupted love in a pious religious setting but later insists that they forgo their plan since they have already enjoyed this pleasure in the imagination: "Don't let us go to Orvieto" (27).

The plot then shifts to the Abruzzo when Giorgio's mother asks him to return home to help deal with the family affairs that have been neglected by his dissolute father, now living with a mistress, a former chambermaid, at the family's country estate. In his "paternal house" Giorgio is confronted with his own impotent authority. His mother and sisters want him to intervene on their behalf but he is unable to summon his will to carry out any kind of action. His father pleads for money to pay off his debts, which Giorgio disdainfully gives him. His contemptible father makes Giorgio realize that he himself is a "corrupt seed." He feels guilty for failing to help his mother and becomes increasingly obsessed with death after entering the room where his uncle Demetrious, whose wealth Giorgio inherited, committed suicide. Bewildered and disoriented, he retreats to what he calls the Hermitage, a secluded home amid a glorious countryside overlooking the sea, and to heal himself from his suicidal thoughts he calls Ippolita to come from Rome and join him.

At this point, the narrative turns to the people and natural geography of the Abruzzo, described mostly from Giorgio's point of view, as, for example, the instructions he gives Ippolita on how to reach the Hermitage:

[F]rom the station of San Vito to the Hermitage takes three quarters of an hour by road; and to cover this distance, the only means is to follow on foot the path cut through the granite, rising perpendicularly from the sea. You must be careful to come provided with heavy shoes, and gigantic parasols. As to the dresses, it is useless to bring many; a few gay and durable costumes for our morning walk will suffice. Do not forget your bathing suit. (168)

His instructions consist of a list of what is required on entering this wild land-the heavy shoes, gigantic parasol, durable clothes and bathing suit. Giorgio's eye, like a Baedeker, scrutinizes the territory, masters its geographic details, and arranges and deepens the scene as an object of tourism.

From the Hermitage high above the sea Giorgio has a commanding view of the countryside and the narrative positions the reader as the viewer of a Michetti landscape painting and in effect transcribes the Abruzzo as an aesthetic tableau. D'Annunzio, now with a painter's eye, transforms objects with highly imagistic prose. Giorgio is "intoxicated" by a scene represented with kaleidoscopic language - the air is crystal and scented, the city is glimmering; the sky is azure, and the entire coast is "under a sweet smelling golden mantle of furze" (162). Another such literary translation of a Michetti painting, this time the idyllic Mattinata, occurs later on when Giorgio encounters five peasant girls gathering furze flowers and singing Abruzzese folksongs (173).

The Abruzzo gradually takes on magical connotations. Mountains are anthropomorphized into breasts and some elements inevitably "trouble the eyes" of the modern observer on encountering the region's primitive religious cults. We are introduced, for example, to the famous Abruzzese ritual where women, children and men with snakes curled around their necks and arms worship the Madonna, such references drawing attention to the distinction between "our" modern metropolitan world where religion is silent and rites are forgotten and "their" world, still full of mystery and phantoms.

When finally a "very pale" Ippolita arrives from Rome (177), the mood of the narrative shifts dramatically and the magical world of the Abruzzo is transformed into a more sinister 
setting where death and decay is associated with the feminine. The first signal occurs when Giorgio and Ippolita, during one of their walks around the Hermitage, encounter a tired and gaunt shepherdess covered in rags and issuing "incomprehensible whimpering" from her toothless mouth (189). During another walk they encounter a family with a sickly infant, a "miserable, emaciated, greenish, naked creature crying constantly, in his cradle that is like a coffin" (195). Ippolita, notes a surprised Giorgio, takes an inordinate interest in the sickly child whose life, the peasants believe, is being sucked by a ghoul.

Although when they were in Rome Giorgio was reluctant to visit the convent of Orvieto, now in the Abruzzo he, like a character in a Barrés novel, wants to come closer to his "race" and its religious rites. Giorgio and Ippolita thus make a pilgrimage to the rustic sanctuary of Casalbordino, which he describes as a redemptive experiment. But Giorgio's admiration for the peasantry turns into unqualified horror when the two reach Casalbordino and are swarmed by a grotesque assembly of filthy, ignorant beggars and invalids, abjectly seeking a miraculous cure from the Virgin. The pilgrimage is described as pure witchcraft, a "boiling cauldron" of brutal appetites, greedy priests, and commercialism, while the spasms of the crowd are associated with the feminine and specifically with Ippolita and her epileptic convulsions. This famous scene, which runs for nearly forty pages (257-96), further illustrates the power of D'Annunzio's prose which through the rhythmic repetition of words and the accumulation of images conjures up a scarifying spectacle of a crowd that embodies "all the filthiness of vice and its stupidities, all the spasms and deformities of baptized flesh,... the howls of the possessed, the shouts of ambulatory vendors, the clanging of the bell,... the squeal of the trumpets" (257) and so on. The description of the religiously fanatic and monstrously deformed crowd crawling along "like reptiles" (270) towards the statue of the Madonna recalls both Michetti's painting and Cesare Lombroso's sociology of crime and degeneration. ${ }^{38}$

The scene of the pilgrimage to Casalboldino is a horrific parade of all that is disturbing, exotic, and "other." Many of Giorgio's perceptions of the Abruzzo are stereotypical: every peasant he meets is superstitious, calculating, shrewd, and infected with religious fanaticism. Or, alternatively, the peasants are the bearers of an ancient, incomprehensible, vital Dionysian strength that can be tapped and controlled only by an ideal type drawn from the upper strata of human society. These striking contrasts are integral to Giorgio's meditation on the Superman. Immediately after his horrific visit to Casalbordino and his feeling of estrangement from his people, Giorgio returns to the Hermitage and is deeply moved by the beauty of the harvest festival and his thoughts wander to his ideal hero, the Nietzschean Zarathustra. Where, he asks, is "the strong tyrannical dominator, free from the burden of any false morality" who can raise himself "above Good and Evil by the energy of his will"? (Il Trionfo, 219). He reflects on the lessons of Zarathustra and how to fight the "feminization of the ancient European soul" and the "rebirth of Christianity among the decrepit races" (Il Trionfo, 221). ${ }^{39}$ He then rhetorically wonders if he himself could be the one who is beyond good and evil for whom everything is permitted.

At this point a piano is brought into the Hermitage and the score of Wagner's Tristan und Isolde brings the narrative to its tragic conclusion as the assertive thoughts of Zarathustra are replaced by the yielding Tristan. The memory of the extraordinary excitement that Giorgio experienced while watching a performance of that work at Bayreuth dominates his imagination. Giorgio's virtuoso description of Wagner's music and the impressions made by the amphitheater, with its arches and pillars and hidden orchestra, offers yet another synthesis 
for the reader, the transformation from hearing music to seeing the death drama. The music and the meaning it conveyed is described as a searing flame, a conflagration that rises to a frenzied pitch before it yields to an awareness of his own tragic destiny. ${ }^{40}$

After the intense excitement of this musical interlude, Ippolita announces that the summer is almost over and that she needs to return to Rome. Giorgio's thoughts about his lover turn more bloody-minded: Ippolita has feminized him. She is a succubus. She has a sexual power over him which he cannot break. Her "barren womb is a furnace" in which his "seed and energy" is destroyed (307). Her lower class origins are revealed by her vulgarity and defects. Her toes are "deformed and plebeian." She is impure and he would "never succeed in making her pure" (306). While he is being reduced as a man, the sun, the open air, and the sea have "favoured the development of her animalism" (336) and she is no longer pale. Giorgio suspects that once back in Rome she will find another lover. Unable to bear this thought and overwhelmed by the music of Tristan und Isolde, he succumbs to the fantasy of a beautiful death: Ippolita's once pale complexion would reach "the perfection of beauty in death," and since he cannot find meaning in this world he desires fulfillment through his own death. This ending, his "funereal seduction," reads like a rape scene. He gets Ippolita drunk on champagne, leads her to the promontory, clutches her in a deadly embrace, and leaps into the sea in a final triumphant Wagnerian liebenstod.

\section{Conclusion}

The Triumph of Death is often dazzling, particularly in the ways D'Annunzio represents an enchanted Abruzzo populated by lesser humans and potential Supermen by drawing on Decadent art (painting, opera, and literature), Dostoevsky, private love letters, and even... on a Baedeker. We should not be seduced, however, by the beauty of the symphony of death the text aspires to, nor should we suggest that the sordid death and overbearing masculine ideology are somehow transcended by the novel's rich imagery and poetic language. We know too much about D'Annunzio's contributions to Italian fascism to return the novel to the canon of "great literary books" where in many senses it belongs, and leave it at that. Rather, we are forced to ask questions about the novel's ideological messages and their entanglements with the structures of references and feelings that are part of Italian fascism and fascist power more generally. ${ }^{41}$

With Giorgio Aurispa, D’Annunzio has not yet created the ideal D'Annunzian Superman. He is no Claudio Contelma of the Virgins of the Rocks who wants to sire new progeny to lift and guide the nation forward, nor Stelio Efrena of The Flame who heats up emotions and mobilizes the crowd with his poetry and rhetoric. Giorgio is more like Dostoyevsky's Raskolnikov in Crime and Punishment, a person who is driven by his obsessions. Unlike Dostoyevsky, D'Annunzio does not morally question Giorgio's thoughts but expresses his aesthetic fascination with them. D'Annunzio was brilliant when it came to describing the feelings of psychological devastation of the "superfluous man," as he was called by nineteenth-century Russian writers - the unfulfilled person who is exposed to feelings of inferiority and who responds to powerlessness with pointless acts of self-destruction. ${ }^{42}$

At the core of Giorgio's resentment stands Ippolita: by growing stronger she becomes "the enemy" that saps his will to the point where the only recourse he can imagine is to kill her in a supreme act of Nietzschean self-affirmation and aesthetic pleasure. The text thus offers a resolution to Giorgio's existential crisis: This "St. George" will destroy the vampiric 
female "monster," and his own suicide will make victory all the more glorious. The feeling that Giorgio's selfhood has been undercut by the Other exemplifies the reactionary political message of the novel. Unlike liberal and left-leaning critiques of culture, which have as their focus the transformation of consciousness and of the self, reactionary ideologies base their critiques on demonizing the other who can then be easily dispatched without guilt.

D'Annunzio's work thus took on a political significance that it was impossible to ignore during the Great War and the rise of Italian Fascism. In Confession of a Non-Political Man, Thomas Mann, after witnessing how popular sentiments were manipulated for the war effort during the First World War, warned against the dangers of the aestheticization of politics. The chief aim of politics, he stated, is or should be the practical considerations of statecraft. D'Annunzio-whom Mann called "Wagner's monkey"43 - used his seductive rhetoric to incite men to sacrifice themselves for the nation. His theatrical posturing and language, full of colour and music, while arousing popular sentiments, did not deepen the public's understanding of political life. Mann is, of course, broadly correct, but he seems to have missed an important point about modern mass politics. ${ }^{44}$ D'Annunzio appealed to the fear, anxieties and lost identities of a people as well as to its sense of glory and power. He addressed collective fantasies of an imagined community and dominated this political idiom, while traditional politicians, exhausted by years of war, tried to draw public attention to Italy's practical national interests.

D'Annunzio achieved his strongest political influence immediately after the First World War when he and a motley group of demobilized soldiers, artists and nationalists, occupied the then Yugoslavian port city of Fiume (now Rijeka, Croatia) in September of 1919. The occupation lasted sixteen months until they were forcibly removed by the Italian government of Giovanni Giolitti in January of 1921. D’Annunzio and his band of legionnaires took over the city because they felt that the Allied powers had compromised Italy's claims to the spoils of victory at the peace table of Versailles. The Allies had offered Italy a "mutilated victory" when they awarded the multiethnic city of Fiume to Yugoslavia, a nation cobbled together from the remains of the Austro-Hungarian empire. The occupation was a colorful political spectacle and D'Annunzio and his legionnaires were able to create many of the mass rituals and rhetorical flourishes that came to be associated with fascism: the Fascist salute, the liturgy of the fallen warrior, and the importance of music. In Fiume, which D'Annunzio renamed the "city of the holocaust" whose flame would purify the nation, he expanded the concept of the political by fusing the autocratic, the theatrical, and the libertine, as a kind of prototype of a fascist political aesthetic. ${ }^{45}$

Italian Fascism was initially less programmatic than its German counterpart and was, as Umberto Eco noted, a "fuzzy totalitarianism," ${ }^{6}$ capable of accommodating Decadent figures like D'Annunzio. The study of fascism over the past forty years has focused on the role played by aesthetics in its political appeal, and the degree to which fascist power expressed itself visually and theatrically. Emilio Gentile suggests that fascism has to be understood as a civic religion that immerses people in a world of symbolism and liturgy. More than an ideology that can be explained rationally, fascism is faith in a myth that reflects the desires and fears of a society. ${ }^{47}$

A work of literature like The Triumph of Death is not, of course, "fascist" but it can reveal some of the emotional fears and symbolic codes that circulate within and influence political culture. Fascism was fixated on sex and reproduction and in particular on disciplining them in the service of the state. But it also focused on placing sexuality in the service of destruction 
and in linking sex to obedience and domination. ${ }^{48}$ In his film Saló, or the 120 Days of Sodom (1976), Pier Paolo Pasolini explores the last days of Mussolini's regime in a way that has particular relevance for understanding fascist power. In the film Pasolini, through the lens of Dante and the Marquis de Sade, de-aestheticizes fascist power and depicts it as a cold ritualized cruelty where sex has been drained of pleasure and turned into a pornographic machine the aim of which is to produce death and obedience. ${ }^{49}$ While Pasolini's graphic images may make viewers wince, the film effectively dramatizes the relationship between sexuality and arbitrary power. To extrapolate from the film, once we strip away the aesthetic fig-leaves - the rituals, marches, theatre and music-with which D'Annunzio and fascism covered the political and which, as Susan Sontag argues, gives it its "fascination" and enormous emotional appeal, ${ }^{50}$ we are left with a hellish system dedicated to the production of death, the reduction of human bodies to things, and the rationalization of cruelty.

\section{Notes}

1. There are a number of very good recent biographies of D'Annunzio in English: Woodhouse's Gabriele D'Annunzio is the most academic and comprehensive; Hughes-Hallett's more popular The Pike is a skilful interpretation of the poet and an enjoyable read; while in D'Annunzio the French writer Philippe Jullian does an excellent job placing D’Annunzio within the European context of Decadent literature and aestheticism.

2. Il Piacere was originally translated by Giorgina Harding in a highly bowdlerized version, but has more recently been carefully translated by Gochin Raffaelli as Pleasure. I have based my reading on the original Italian Il Trionfo della Morte and have drawn the quotations from Arthur Hornblow's translation, The Triumph of Death, page references to which are hereafter cited in the text. This translation is heavily edited and missing some key passages, notably about Ippolita's complexion turning "olive." Most importantly, Giorgio's meditation on Nietzsche and Zarathustra has been excised. When quoting from those passages I have added the page numbers from the original Italian to my translations. The Triumph of Death still awaits a modern English translator. For an excellent account of how the novel was reworked and edited for an English audience originally, see Woodhouse, "Trionfo della Morte," 239-60.

3. The book is dedicated to Matilde Serao whose realistic, sociological novel about the Neapolitan urban classes, Il Ventre di Napoli (1884), exemplifies the kind of realist literature from which D’Annunzio wanted to distance himself.

4. Quoted in Giordano Guerri, D'Annunzio: L'amante guerrerio, 72. Guerri is a historian of Italian fascism and currently the president of the Fondazione Il Vittoriale degli Italiani. Il Vittoriale is the "hermitage" and mausoleum D'Annunzio built at Lake Garda towards the end of his life. Guerri, along with Paola Sorge, author of D'Annunzio, are two public intellectuals who have been at the forefront of rekindling popular interest in D'Annunzio's works.

5. In his famous essay “The Work of Art," 217-51, Benjamin noted the Futurist and Fascist proclivity to beautify the machine, death, and destruction and pointed out how such appeals were part of the aestheticization of politics.

6. D’Annunzio's creative "borrowing" from Verga's style and narrative structure has been examined in Paratore, D'Annunzio e Verga.

7. Härmänmaa notes that D'Annunzio was responding to market forces that encouraged the production of texts with violence and sex. See her "Celebrating Decadence," 698-714.

8. Praz, The Romantic Agony, 420-21; see also the original text, La Carne, la morte, 377-78.

9. Rhodes, The Poet as Superman, 35.

10. The Italian scholarship on D'Annunzio and the Abruzzo is substantial. Härmänmaa provides a very useful account of that work in "Celebrating Decadence." The main sources include: Giannangeli, D’Annunzio e L'Abruzzo; Mariano, L'Arte di Gabriele D’Annunzio; Tiboni and Abrugiati, Trionfo della morte; Circeo, L'Abruzzo; and Masci, Gloria alla Terra! Much of this 
scholarship is extraordinarily thorough and resourceful about D'Annunzio's relationship to his home province and its language, cults, rituals, and history of violence. For a broader discussion of D'Annunzio's contribution to a national imaginary and the ways in which various Italian writers have represented the "national-popular," I have relied on Asor Rosa, Scrittori e Popolo. Asor Rosa follows a Gramscian tradition and treats D’Annunzio as a writer who contributed to the literary construction of "barbaric populism" which was chiefly the creation of a group of petit-bourgeois intellectuals and, as I elaborate, was filtered through the influences of Nietzsche, Wagner, and Decadent literature. Asor Rosa's book, originally published in 1965, has been updated in 2015 and includes a new section called scrittori e massa, which examines Italy's transformation since the 1960s and the withdrawal of the new generation of intellectuals from engagement with national, regional, and popular issues into solipsism and individualism.

11. See Giannangeli, "D’Annunzio e l'Abruzzo del mito," 51-68, and Härmänmaa, "Celebrating Decadence."

12. For examples of invented traditions that combine anthropological and historical insights, see Hobsbawm and Ranger, The Invention of Tradition. Perhaps the most influential work on national imaginary is Anderson's Imagined Communities.

13. Williams used the phrase "structures of feelings" in The Long Revolution. For the social or cultural historian, recapturing or reclaiming the animating ideas and feelings of a period is always problematic. There are, however, discernible patterns within cultures and examining the textual references that point to the lived experience within a culture is a fruitful way of reconstructing the past and linking it to the present.

14. A detailed treatment of D'Annunzio’s candidacy and speeches is found in Gentile, "D’Annunzio come deputato," 237-58. D’Annunzio's famous letter is quoted in Woodhouse, Gabriele D’Annunzio, 164.

15. During the period he was writing The Triumph of Death D'Annunzio published several articles in the Italian press on the ideas of Nietzsche and Wagner: "La bestia elettiva," published in Il Mattino in 1892, and three articles on "Il caso Wagner" in La Tribuna in 1893. For the English translation of "La bestia elettiva," see Schnapp,"The Beast Who Wills," 265-78. For the influence of Nietzsche on Italian intellectual culture of the period, see Michelini, Nietzsche nell'Italia di d'Annunzio. The scholarship on D'Annunzio and Nietzsche is not as vast as that on D’Annunzio and Wagner and for good reason. D’Annunzio had a superficial understanding of Nietzsche and used his ideas mostly to justify his own transgressive behavior and megalomania. The power of music was for him decidedly more important than that of ideas and he felt that only music could express the subjective unease induced by modernity. His relationship to Wagner (and music) remained important throughout his life. D’Annunzio's three articles on the debate between Nietzsche and Wagner are collected in Il caso Wagner; see also Sorge's introduction, "D’Annunzio tra Wagner e Nietzsche," 1-19.

16. Nietzsche's unsent letter to Carducci has fed a certain historical curiosity about the philosopher's last year of lucidity. See Stern, "The Trouble with Publishers."

17. Though the two never met, Nietzsche had a lasting admiration for Carducci. For Nietzsche's letter to Carducci, see also Benozzo, Carducci, 85.

18. While still a student at Cicognini College, the young D'Annunzio bought a copy of Carducci's Barbarian Odes on his first visit to Bologna in 1878. He described reading it as an epiphany and the poems deeply influenced his own early poems.

19. See Schnapp, "Nietzsche's Italian Style," 247-64.

20. The Will to Power was partially falsified by Nietzsche's doctrinaire sister, Elizabeth FörsterNietzsche. In the 1960s the Italian scholars Colli and Montinari did much of the pioneering work to reclaim Nietzsche from Fascist and Nazi interpretations, especially with regards to The Will to Power. The Colli and Montinari edition of Nietzsche's complete original work is currently being published in English by Stanford University Press. See Nietzsche The Complete Works.

21. For an informative account of the influence of Wagner in Italy and the debates between Nietzsche and Wagner, see Mila, Cronache Wagneriane, 47.

22. See Nietzsche, The Case of Wagner, 14. 
23. See Nietzsche's Preface to "The Case of Wagner," xxx.

24. The original Italian reads: "Riccardo Wagner... ha rivelato a noi stessi la parte più occulta di nostra intima vita." Il caso Wagner, iii.

25. Asor Rosa, Scrittori e popolo, 96-97.

26. The political significance of verismo is given substantial treatment in the first chapter of Asor Rosa's Scrittori e popolo. The rise of verismo in opera begins with Mascagni's Cavalleria rusticana and includes other works such as Ruggero Leoncavalli's Pagliacci and Puccini's Tosca. See Mallach, Autumn of Italian Opera. D'Annunzio was turning away from verismo by the time the opera Cavelleria rusticana came out and was dismissive of Mascagni's work when he first heard it and called him a band-leader. Later he had a productive and somewhat stormy collaboration with him. On the relationship between the two, see Celati, Il vate e il capobanda.

27. Sorge, Sogno di una sera d'estate, 7. Sorge provides a biographical sketch of the major and minor figures that were part of Il cenacolo. For a more personal account of the relationship between D'Annunzio and Michetti, see Di Tizio, D'Annunzio e Michetti.

28. In 1999 there was a major retrospective exhibition of Michetti's work in Naples. See the Catalogo della Mostra retrospettiva.

29. Quoted in Wilcken, Il poeta nel laboratorio, 289.

30. The relationship between D'Annunzio and Wagner, like that of D'Annunzio and the Abruzzo, is the subject of a large number of studies. See in particular Paratore, "D'Annunzio e Wagner" 101-17; Corazzol, Sensualità senza carne; Mila, Cronache Wagneriane; and Sorge, “D’Annunzio tra Wagner e Nietzsche."

31. James at first showed great admiration for the Italian poet but grew more critical of him. See James, Selected Literary Criticism.

32. For James's commentary on D’Annunzio's representation of exasperated sensibility, see Hughes-Haslett, The Pike, 201.

33. Lewis discusses D'Annunzio's novels and nationalism in Modernism, Nationalism and the Novel.

34. On the importance of the countryside to the modern nation in both Maurice Barrès and D’Annunzio, see Tosi, "Il personaggio di Giorgio Aurispa," 96-113.

35. "Noi tendiamo l'orecchio alla voce del magnanimo Zarathustra, o Cienobiarca; e prepariamo nell'arte con la sicura fede l'avvento dell'ÜEBERMENSCH, del superuomo" (Il Trionfo, 12).

36. On the relationship of D'Annunzio's novels with imperialism, see my "Sex, Geography and Death," 35-68, which draws on both Jameson's The Political Unconscious and Said's Orientalism.

37. For an overview of the influence of Huysmans' Against Nature on Decadent literature, see Pierrot, The Decadent Imagination.

38. Spackman in Decadent Geneologies offers an insightful reading of the Casaldordino scene and its connection with the discourses of sickness and degeneration of both Cesare Lombroso and Max Nordau.

39. Hornblow excised the section on Nietzsche, thinking the philosophical passage interfered with the narrative. But the passage is crucial to understanding Giorgio's wish to overcome his weakness and justify the murder of Ippolita. "Dove vive il dominatore... forte e tirannico, franco dal gioco di ogni falsa moralitá... determinato ad elevarsi sopra il Bene e sopra il Male per la pura energia del suo volere..."? (Il Trionfo, 219). Later, Giorgio makes reference to the need of the Superman to resist and fight: "tutta la ridevole e miserevole effeminazione della vecchia anima europea, tutte le mostruose rifioriture della lue cristiana nelle razze decrepite" (221).

40. Furness has examined the influence of Wagner on European literature of the period and offers a brief and perceptive analysis of The Triumph of Death in Wagner and Literature.

41. Examining the "correspondences," "homologies" or "entanglements" between the formal structures of a narrative and the historical and sociological settings has been the focus of a new generation of scholars since the 1960s. See in particular Eco, Il Superuomo di Massa.

42. The superfluous man is a figure that emerges from Russian literature and captures the nihilism and fatalism of a generation of young, bored men. D’Annunzio was aware of this literary 
figure through his readings of Russian literature and Dostoevsky in particular. See Chances, "The Superfluous Man."

43. For Mann's excoriating comments on D’Annunzio, see Reflections, esp. 420-35.

44. Mann's position was, to put it simply, that politics was Apollonian and art was Dionysian. Mixing them is dangerous and artists should stick to an ironic self-distancing from political life. Resistance to Fascism, and indeed to any form of reactionary movement that "aestheticised politics," requires, however, a more activist response and has its own risks. Hence Benjamin's call in "The Work of Art" to "politicise aesthetics." Benjamin's remark asks us to think more critically about aesthetics and dig into its various cultural and psychological underpinnings as a way of understanding and countering its powerful appeals.

45. The Fiume escapade is discussed in Leeden, The First Duce; see also Gumbrect, "I rendentori della vittoria," 253-72.

46. Eco discusses the concept of "fuzzy totalitarianism" in "Ur-Fascism," 12-15. For an early commentary on D'Annunzio and the relationship between politics and aesthetics, see de Felice, Pampaloni, Paratore, and Praz, Gabriele D’Annunzio.

47. Since the pioneering work of Gentile, The Sacralization of Politics, first published in 1993, there has been a significant increase in studies on fascism and its relationship to aesthetics. For a broader discussion of fascist aesthetics, see "The Aesthetics of Fascism"; see also Mosse, Masses and Men; and Falasca-Zamponi, Fascist Spectacle.

48. See Theweleit, Male Fantasies; see also Mosse, Nationalism and Sexuality; and Spackman, Fascist Virilities.

49. Pier Paolo Pasolini, Il Mio Cinema, esp. "Il sesso come metafora del potere," 215-19. Pasolini is an appropriate figure with whom to close this examination, for he was among the few contemporary Italian intellectuals who lucidly explored both the utopian and dystopian dimensions of sexuality and power.

50. Sontag's "Fascinating Fascism" is both a critical exposé of the Nazi propaganda filmmaker Leni Riefenstahl's attempt at public rehabilitation and a brilliant analysis of how her films, particularly Triumph of the Will, represent a transformation of history into theatre. The film may be aesthetically pleasing but hidden underneath its chilling beauty are the messages of control, submissive behavior, and the glamorization of death.

\section{Bibliography}

“The Aesthetics of Fascism.” Special Issue, Journal of Contemporary History 31(2) (1996).

Anderson, Benedict. Imagined Communities: Reflection on the Origins and the Spread of Nationalism. New York: Verso, 1991.

Asor Rosa, Alberto. Scrittori e popolo 1965. Scrittori e massa 2015: Il populismo nella letteratura italiana contemporanea. Torino: Piccola Biblioteca Einaudi, 2015.

Benjamin, Walter. "The Work of Art in the Age of Mechanical Reproduction." In Illuminations, edited by Hannah Arendt. New York: Schocken Books, 1976.

Benozzo, Francesco. Carducci. Roma: Salerno Editrice, 2015.

Catalogo della Mostra retrospettiva di Francesco Paolo Michetti. Napoli: Electa, 1999.

Celati, Giovanni. Il vate e il capobanda: D’Annunzio e Mascagni. Roma: Belforte, 1992.

Chances, Ellen. “The Superfluous Man in Russian Literature." In The Routledge Companion to Russian Literature, edited by Cornell Neill. New York: Routledge, 2001.

Circeo, Ermanno, ed. L'Abruzzo in D'Annunzio. Pescara: Ediars, 1995.

The Complete Works of Friedrich Nietzsche, Vol. I-XV: Based on the Edition by Giorgio Colli and Mazzimo Montinari. Stanford, CA: Stanford University Press, 2016.

D’Annunzio, Gabriele. Pleasure. Translated by Lara Gochin Raffaelli. New York: Penguin Classics, 2013; originally published as Il Piacere 1889. Translated by Giorginia Harding. Verses translated by Arthur Symons. New York: Boni and Liveright, 1925.

D’Annunzio, Gabriele. Il Trionfo della Morte. Edited by Gianni Oliva. Roma: Grandi Tascabili Economici Newton, 1995; The Triumph of Death. Translated by Arthur Hornblow. New York: George H. Richmond, 1895. 
D’Annunzio, Gabriele. Lettere a Barbara Leoni (1887-1892). Edited by Vito Salierno. Lanciano: Carabba, 2008.

D’Annunzio, Gabriele. Libro Secreto. Edited by Gianni Oliva. Roma: Grandi Tascabili Economici Newton, 1995.

De Felice, Renzo, Geno Pampaloni, Ettore Paratore, and Mario Praz. Gabriele D’Annunzio. Bologna: M. Boni, 1978.

Di Tizio, Franco. D’Annunzio e Michetti. La verità sui loro rapporti. Chieti: Mario Ianieri Editore, 2002.

Eco, Umberto. Il Superuomo di massa: Retorica e ideologia nel romanzo popolare. Milano: La Nave di Teseo, 2016.

Eco, Umberto. “Ur-Fascism." The New York Review of Books, June 22, 1995.

Falasca-Zamponi, Simonetta. Fascist Spectacle: The Aesthetics of Power in Mussolini's Italy. Berkeley: University of California Press, 1997.

Furness, Raymond. Wagner and Literature. New York: St. Martin’s Press, 1982.

Galbo, Joseph. "Sex, Geography and Death: Metropolis and Empire in a Fascist Writer." Environment and Planning D: Society and Space 14 (1996): 35-58.

Gentile, Panfio. “D’Annunzio come deputato." In Gloria e Terra! Gabriele D’Annunzio e L’Abruzzo, edited by Maglio, Masci. Pescara: Editrice DAnnunzia Abruzzese, n.d.

Gentile, Emilio. The Sacralization of Politics in Fascist Italy. Cambridge, MA: Harvard University Press, 1996.

Giannangeli, Ottaviano. D’Annunzio e L’Abruzzo: Storia di un Rapporto Esistenziale e Letterario. Chieti: Marino Solfanelli, 1988.

Guarnieri Corazzol, Adriana. Sensualità senza carne. La musica nella vita e nell' opera di D’Annunzio. Bologna: Il Mulino, 1990.

Guerri, Giordano Bruno. D’Annunzio: L’amante guerrerio. Milano: Oscar Mondadori, 2008.

Gumbrect, Hans Ulrich. "I rendentori della vittoria: On Fiume's Place in the Genealogy of Fascism." Special Issue: The Aesthetics of Fascism. Journal of Contemporary History 31(2) (1996): 253-72.

Härmänmaa, Marja. “Celebrating Decadence: The Image of Abruzzo in D’Annunzio’s Trionfo della morte." The European Legacy 18(6) (2013): 698-714.

Hobsbawm, Eric, and Terence Ranger, eds. The Invention of Tradition. Cambridge: Cambridge University Press, 2012.

Hughes-Hallett, Lucy. The Pike: Gabriele D’Annunzio Poet, Seducer and Preacher of War. London: Fourth Estate, 2013.

Huysmans, J. K. Against Nature. Translated by R.Baldick. Harmondsworth, UK: Penguin, 1959.

James, Henry. Selected Literary Criticism. Edited by Morris Shapira. Cambridge: Cambridge University Press, 1981.

Jameson, Fredric. The Political Unconscious: Narrative as a Socially Symbolic Act. Ithaca, NY: Cornell University Press, 1981.

Jullian, Philippe. D’Annunzio. London: Pall Mall Press, 1972.

Leeden, Michael. The First Duce: D’Annunzio at Fiume. Baltimore, MD: Johns Hopkins University Press, 1977.

Lewis, Pereclis. Modernism, Nationalism and the Novel. Cambridge: Cambridge University Press, 2000. Mallach, Allen. The Autumn of Italian Opera: From Verismo to Modernism, 1890-1915. Lebanon, NH: North Eastern University Press, 2007.

Mann, Thomas. Reflections of a Nonpolitical Man. Translated by W. D. Morris. New York: Viking Press, 1983.

Mariano, Emilio, ed. L'Arte di Gabriele D’Annunzio. Milano: Mondadori, 1968.

Masci, Maglio, ed. Gloria alla Terra! Gabriele D’Annunzio e L’Abruzzo. Pescara: Editrice D’Annunzia Abruzzese, n.d.

Michelini, Gaia. Nietzsche nell'Italia di d'Annunzio. Palermo: Flaccovio, 1978.

Mila, Massimo. Cronache Wagneriane. Edited by Piero Gelli. Milano: BUR, Rizzoli, 2013.

Mosse, George. Masses and Men: Nationalist and Fascist Perception of Reality. Detroit, MI: Wayne State University Press, 1985.

Mosse, George. Nationalism and Sexuality: Respectability and Abnormal Sexuality in Modern Europe. New York: Fertig, 1985. 
Nietzsche, Friedrich. The Case of Wagner, Nietzsche Contra Wagner, Selected Aphorisms. Translated by Anthony Ludovici. London: T. N. Foulis, 1911.

Nordau, Max. Degeneration (1892). Translated from the second edition of the German work. Introduction by George L. Mosse. Lincoln: University of Nebraska Press, 1993.

Paratore, Ettore. D’Annunzio e Verga: nuovi contributi a una recerca apparentemente conclusa. Roma: Edizioni dell'Ateneo, 1963.

Paratore, Ettore. “D’Annunzio e Wagner." Quaderni del Vittoriale 36 (1982).

Pasolini, Pier Paolo. Il Mio Cinema. A cura di Graziella Chiarcossi e Roberto Chiesi con la collaborazione di Maria Agostini. Bologna: Cineteca, 2015; originally published in Corriere della Sera, Marzo 25, 1975.

Pierrot, Jean. The Decadent Imagination, 1880-1900. Translated by D.Coltman. Chicago, IL: University of Chicago Press, 1981.

Praz, Mario. The Romantic Agony. Translated by Angus Davison. Birkendead: Fontana, 1970; originally published in 1930 as La Carne, la morte, e il diavolo nella letteratura romantica.

Rhodes, Antony. The Poet as Superman: The Life of Gabriele D'Annunzio. London: McDowell Obolensky, 1959.

Said, Edward. Orientalism. New York: Vintage Books, 1979.

Schnapp, Jeffery. "Nietzsche's Italian Style: Gabriele D’Annunzio." In Nietzsche in Italy, edited by Thomas Harrison. Saratoga, CA: Anma Libri, 1988.

Schnapp, Jeffrey, trans. "The Beast Who Wills." In Nietzsche in Italy, edited by Thomas Harrison. Saratoga, CA: Anma Libri, 1988.

Sontag, Susan. "Fascinating Fascism." The New York Review of Books, February 6, 1975.

Sorge, Paola. D’Annunzio: Vita di un Superuomo. Roma: Castelvecchi, 2013.

Sorge, Paola. Sogno di una sera d'estate: d'Annunzio e il cenacolo Michettiano. Pescara: Ianerie, 2013.

Spackman, Barbara. Decadent Genealogies: The Rhetoric of Sickness from Baudelaire to D'Annunzio. Ithaca, NY: Cornel University Press, 1989.

Spackman, Barbara. Fascist Virilities: Rhetoric, Ideology, and Social Fantasy in Italy. Minneapolis: University of Minnesota Press, 2008.

Stern, Fritz. “The Trouble with Publishers." Review of The Nietzsche Canon: A Publication History and Bibliography, by William Schaberg. London Review of Books, September 19, 1996.

Theweleit, Klaus. Male Fantasies. 2 vols. Minneapolis: University of Minnesota Press, 1987.

Tiboni, Edoardo, and Luigia Abrugiati, eds. Trionfo della morte. Atti del III Convegno Internazionale di studi dannunziani. Pescara: Centro di studi dannunziani, 1981.

Tosi, Guy. "Il personaggio di Giorgio Aurispa nei suoi rapporti con la cultura francese." In Trionfo della morte. Atti del III Convegno Internazionale di studi dannunziani, edited by E. Tiboni and L.Abrugiati, 87-142. Pescara: Centro di studi dannunziani, 1981.

Wilcken, Patrick. Il poeta nel laboratorio: Vita di Claude-Lévi Strauss. Milano: Il Saggiatore, 2010.

Williams, Raymond. The Long Revolution. New York: Penguin Books, 1984.

Woodhouse, John. Gabriele D’Annunzio: Defiant Archangel. Oxford: Oxford University Press, 1998.

Woodhouse, John. "Trionfo della morte: traduzioni, e interpretazioni anglosassoni." In Il trionfo della morte: Atti del III Convegno Internazionale di studi dannunziani, edited by E.Tiboni and L.Abrugiati, 239-60. Pescara: Centro di studi dannunziani, 1981. 